\title{
Strategi Pengembangan Objek Wisata Berwawasan Lingkungan (Studi pada Objek Wisata Wair Nokerua, Desa Kolisia, Kabupaten Sikka)
}

Elisabeth Evenince ${ }^{1 *}$, Maria Karlina Yunivera De Gerald ${ }^{2}$

1'2Program Studi Ekowisata, Politeknik Cristo Re, Maumere, Indonesia

*surel: elisabethevenince $1 @ g$ gmail.com

\section{ABSTRACT}

Wair Nokerua is one of the tourist attractions in Kolisia Village, Sikka Regency, East Nusa Tenggara and potential to be developed through environmentally development. This study aims to determine the development strategy with an environmental perspective that needs to avoid ecological damage. The method of data analysis was carried out with descriptive qualitative approach. The results showed that the strategy for developing Wair Nokerua tourism objects with the concept of regional zoning, including the core zone, buffer zone and service zone with participatory planning by applying the principles of environmentally sound development, namely the prevention of environmental pollution (paying attention to carrying capacity areas, regulating waste disposal, tourism awareness campaigns and Sapta Pesona to the Kolisia Village community and tourists), rehabilitation and restoration of ecosystems and natural resources that damaged (recovery of damaged coral reefs, replanting plant species in coastal areas, planting sunflowers as a tourist attraction and raising awareness of the need for conservation for managers and tourists) and increasing the production natural capacity and human-built ecosystems (providing training to POKDARWIS Kolisia Village to increase the role and participation of the community in the development of the Wair Nokerua tourist attraction)

\section{INTISARI}

Wair Nokerua merupakan salah satu objek wisata yang ada di Desa Kolisia, Kabupaten Sikka, Nusa Tenggara Timur dan memiliki potensi untuk dikembangkan melalui pengembangan berwawasan lingkungan. Penelitian ini bertujuan untuk mengetahui strategi pengembangan berwawasan lingkungan agar terhindar dari kerusakan ekologis. Metode analisis data dilakukan dengan pendekatan kualitatif deskriptif. Hasil penelitian menunjukan bahwa strategi pengembangan objek wisata Wair Nokerua dengan konsep pembagian zonasi wilayah, antaralain zona inti, zona buffer dan zona pelayanan dengan perencanaan partisipatif dengan menerapkan prinsip pengembangan berwawasan lingkungan yaitu pencegahan pencemaran lingkungan (memperhatikan carryng capacity area, mengatur pembuangan sampah, kampanye sadar wisata dan sapta pesona kepada masyarakat Desa Kolisia dan Wisatawan), rehabilitasi dan pemulihan ekosistem dan sumberdaya alam yang rusak (pemulihan terumbu karang yang rusak, penanaman kembali jenis tumbuhan yang ada di wilayah pesisir, penanaman bunga matahari sebagai atraksi wisata dan meningkatkan kepedulian akan perlunya konservasi bagi pengelola dan wisatawan) dan meningkatkan kapasitas produksi dari ekosistem alam dan binaan manusia (memberikan pelatihan kepada POKDARWIS Desa Kolisia untuk meningkatkan peran dan partisipasi masyarakat dalam pembangunan objek wisata Wair Nokerua) 


\section{PENDAHULUAN}

Kabupaten Sikka merupakan salah satu kabupaten yang ada di Nusa Teggara Timur yang memiliki keanekaragaman kekayaan alam, budaya dan adat istiadat. Sumber daya alam yang dimiliki berupa hutan dengan segala isinya, daratan dengan segala bentuknya, serta lautan dengan segala potensinya dapat dimanfaatkan secara terusmenerus untuk kepentingan pembangunan dan untuk pengembangan pariwisata. Potensi tersebut merupakan aset yang harus dimanfaatkan secara optimal melalui kepariwisataan.

Salah satu obyek wisata yang menarik perhatian para wisatawan domestik dan wisatawan asing adalah Objek Wisata Wair Nokerua yang mempunyai kisah sejarah, nilainilai religius dan keunikan alam yang melekat pada destinasi ini sehingga setiap minggu banyak wisatawan yang berkunjung ke tempat ini. Masyarakat Kabupaten Sikka, NTT meyakini legenda ataupun cerita para leluhur bahwa Wair Nokerva (dalam bahasa Sikka, Wair artinya air dan Nokerua artinya imam) merupakan sebuah mata air ajaib peninggalan mukjizat Santo Fransiskus Xaverius yang dapat menyembuhkan berbagai penyakit, memberikan berkat bagi kesuburan tanaman. Keotentikan atau keaslian alam Wair Nokerua masih sangat terjaga, memiliki topografi tanah yang unik, dan juga memiliki daya tarik tersendiri yaitu taman bawah laut yang memiliki berbagai jenis coral, maupun di atas puncak yang merupakan spot utama untuk menikmati matahari terbenam dengan pasir putih terbentang luas sepanjang bibir pantai. Potensi ini jika dikembangkan maka dapat meningkatkan pendapatan nasional maupun pendapatan daerah dalam rangka meningkatkan kesejahteraan dan kemakmuran masyarakat setempat. Selain itu juga dapat memperluas dan memeratakan kesempatan berusaha bagi masyarakat, serta dapat membuka lapangan pekerjaan yang dapat menyerap tenaga kerja sehingga dapat mengurangi jumlah pengangguran.

Untuk dapat meningkatkan potensi pariwisata tersebut, maka perlu adanya pengembangan pariwisata berwawasan lingkungan untuk mendukung pelestarian lingkungan (alam dan budaya) dan meningkatkan partisipasi masyarakat dalam pengelolaan, sehingga dapat memberikan manfaat ekonomi kepada masyarakat dan pemerintah daerah [4]. Pariwisata berwawasan lingkungan bukan sekadar konsep berwisata di lingkungan alam melainkan juga fokus pada pengamatan dan pemahaman mengenai alam dan budaya, mendukung pelestarian, serta lebih mengutamakan fasilitas dan jasa yang disediakan oleh masyarakat setempat [6].

Berdasarkan observasi yang dilakukan peneliti pada objek wisata Wair Nokerua, terlihat bahwa sudah terdapat beberapa sarana dan prasana seperti adanya beberapa kursi bambu panjang dan papan penunjuk arah. Meskipun begitu tempat ini dapat dikatakan belum dikelola secara maksimal. Kursi bambu panjang yang disediakan oleh masyarakat setempat sangat kurang dan ada 
beberapa yang sudah mulai rusak, tidak tersedianya tempat sampah di sekitar objek wisata tersebut, tidak terdapat lapak penjual makanan yang ada di sana sehingga wisatawan yang datang harus membawa makanan/minuman. Hal inilah yang menimbulkan terjadinya banyak sampah yang dihasilkan setiap minggu. Selain itu promosi objek wisata Wair Nokerua maksimal dimana sejauh ini hanya melalui promosi mulut ke mulut (word of mouth promotion) maupun WOM yang ditulis dimedia sosial sangat membantu penyebaran informasi mengenai objek wisata Wair Nokerua. Karena sampai saat ini informasi yang diperoleh mengenai Wair Nokerua masih diperoleh dari media mulut ke mulut dan media sosial dari pengunjung sebelumnya (sumber: Pengunjung objek wisata, Hery.). Berdasarkan wawancara kepada Bapak Kepala Desa Kolisia, pemerinta desa juga memiliki kendala dalam pengembangan Objek Wisata Wair Nokerua yaitu pendanaan pengembangan objek wisata yang masih terbatas serta SDM dengan disiplin ilmu pariwisata yang masih sangat kurang.

Untuk menjadikan Wair Nokerua sebagai objek wisata yang eksotis dan menarik untuk dikunjungi oleh wisatawan domestik maupun mancanegara, diperlukan partisipasi dari semua pihak baik pemerintah daerah, masyarakat setempat dan juga wisatawan. Meningkatnya kesadaran berbagai pihak terhadap lingkungan dan isuisu tentang pembangunan yang berwawasan lingkungan telah memberikan kontribusi terhadap pandangan pentingnya prinsip- prinsip wisata berkelanjutan. Prinsip wisata diharapkan dapat mempertahankan kualitas lingkungan, mempertahankan budaya, meningkatkan kualitas pendidikan, memberdayakan masyarakat lokal, dan memberikan manfaat ekonomi kepada masyarakat lokal, kawasan dan pemerintah [2].

Beberapa studi terdahulu telah membahas dan mengkaji permasalahan pengembangan objek wisata seperti pengembangan pariwisata berwawasan lingkungan atau ekowisata harus dengan prinsip pembangunan berkelanjutan dan diperlukan pemetaan, fungsi lahan menjadi objek wisata [3]. Kemudian pengembangan pariwisata yang berorentasi pada pelestarian lingkungan dan potensi ekonomi di area yang rentan dan berisiko, objek pariwisata ini harus memiliki kemampuan adaptasi dan mitigasi agar tidak membahayakan masyarkat maupun wisatawan serta menimbulkan kerusakan [1]. Dari uraian di atas, penelitian ini bertujuan untuk mengetahui strategi pengembangan berwawasan lingkungan yang perlu dilakukan pada Objek Wisata Wair Nokerva agar terhindar dari kerusakan ekologis.

\section{METODOLOGI}

Lokasi penelitian ini adalah Objek Wisata Wair Nokerua, Desa Kolisia, Kabupaten Sikka. Lokasi penelitian ditentukan dengan pertimbangan bahwa kawasan tersebut memiliki potensi dan daya tarik wisata yang apabila dikembangkan dapat menjadi destinasi wisata di Kabupaten Sikka. Metode 
pengumpulan data dengan menggunakan metode purposive sampling, yaitu memilih secara sengaja sampel yang akan diteliti sebagai responden. Responden yang dipilih berasal dari Ketua Badan Permusyawaratan Desa Kolisia 1 orang, Kepala Desa Kolisia 1 orang, pengelolah objek wisata wair nokerua 1 orang dan tokoh masyarakat 2 orang. Karena responden tersebut dianggap mengetahui informasi mengenai faktor strategis internal dan eksternal objek wisata secara menyeluruh.

Data primer diperoleh dari pengamatan langsung pada lokasi penelitian, observasi, wawancara, dialog dengan masyarakat maupun pemerintah desa. Data sekunder adalah data yang diperoleh dari instansi terkait yang mampu mendukung penelitian ini.

Pengolahan dan analisis data dilakukan dengan pendekatan kualitatif deskriptif dengan memaparkan dan menginterpretasikan semua data dan informasi yang diperoleh dilapangan sesuai dengan masalah dan tujuan penelitian. Penelitian ini dilaksanakan selama 6 (enam) bulan yaitu dimulai bulan November 2020 - Mei 2021 dari mulai survey dan pengumpulan data, pengkajian referensi pendukung hingga proses analisis dan pembahasan.

\section{HASIL DAN PEMBAHASAN}

Kecamatan Magepanda adalah 1 dari 21 kecamatan yang ada di Kabupaten Sikka, Nusa Tenggara Timur, Indonesia. Kecamatan ini berjarak 30 kilometer dari ibukota kearah barat. Pengembangan pariwisata harus di sesuaikan dengan kemampuan kondisi potensi yang ada dan harus mencerminkan tentang tujuan pengembangan yang diharapkan dan bisa dicapai dengan didasarkan pada potensi yang dimiliki dan trend pasar yaitu memahami keinginan dan kebutuhan wisatawan [8].

\section{Matriks Internal Eksternal (IE)}

Dari perolehan total skor IFAS dan EFAS, dapat diketahui posisi objek wisata Wair Nokerua dalam matriks internal eksternal yang di tunjukan dalam Gambar 1.

Pada Gambar 1, diketahui bahwa berdasarkan analisis faktor strategis internal dan eksternal pada objek wisata ini, maka posisi kondisi Internal berada pada posisi ratarata dengan nilai $(1,7)$ dan posisi kondisi Eksternal berada pada posisi tinggi dengan nilai $(3,2)$. Berdasarkan Matrix InternalEksternal tersebut, objek wisata Wair Nokerua berada pada posisi sel III yang dikategorikan pada posisi pertumbuhan (Hold and maintain), sehingga memerlukan strategi pengembangan yang tepat guna meningkatkan kunjungan wisatawan ke Wair Nokerua dengan penetrasi pasar serta penguatan daya tarik wisata (menambah atraksi, infrastruktur, transportasi, fasilitas) dan meningkatkan kualitas pelayanan dan aspek promosi.

\section{Analisis SWOT}

Indikator-indikator

internal

menghasilkan kekuatan dan kelemahan sedangkan indikator-indikator eksternal menghasilkan peluang dan ancaman. SWOT 
adalah identitas berbagai faktor secara sistematis untuk merumuskan strategi pelayanan [5]. Analisis ini berdasarkan logika yang dapat memaksimalkan peluang namun secara bersamaan dapat meminimalkan kekurangan dan ancaman. Berikut ini kekuatan, kelemahan, peluang, dan ancaman yang dimiliki oleh objek wisata Wair Nokerua. Melalui analisis SWOT diperoleh alternative strategi pengembangan yang dapat diterapkan di Objek Wisata Wair Nokerua pada masa yang akan datang.

a. Strengths (S)

1. Kondisi kawasan yang bersih dan terawat

2. Daya tarik wisata yang dapat dilihat

3. Taman bawah laut yang cocok untuk tempat snorkelling dan diving

4. Memiliki panorama pantai maupun tebing yang indah

b. Weaknesses (W)

1. Kondisi jalan menuju lokasi wisata Wair Nokerua belum terawat dengan baik

2. Rumah makan/restaurant yang sedikit dan tidak bervariatif

3. Kurang lengkapnya akomodasi penginapan

c. Opportunities (O)

1. Kebijakan pemerintah dalam bidang pariwisata

2. Lahan parkir bagi pengunjung yang dikelolah oleh POKDARWIS

3. Keanekaragaman serta motivasi pengunjung

4. Peluang usaha bagi masyarakat setempat
5. Adanya sinyal telekomunikasi yang baik

6. Terdapat kantor pengelolaan objek wisata yang dikelolah oleh POKDARWIS

7. Adanya penerapan Sadar Wisata di Wair Nokerua

d. Threats $(\mathrm{T})$

1. Kondisi persaingan antara produk wisata yang serupa

2. Sumberdaya manusia yang belum professional

3. Kurangnya sarana transportasi menuju Lokasi Wisata Wair Nokerua

Dari identifikasi faktor Strengths, Weakness, Opportunity, Threat dapat dirumuskan strategi pengembangan objek wisata Wair Nokerua, yaitu :

1. Strategi SO (Strengths Opportunities / Kekuatan Peluang)

a. Pengembangan Wisata bahari maupun rekreasi air (water sport) di Wair Nokerva sebagai suatu jenis pariwisata alternative dengan memanfaatkan segala potensi yang dimiliki untuk dapat mendatangkan wisatawan dalam skala besar

b. Sosialisasi, penerapan dan pemberdayaan sadarwisata dari pemerintah pada masyarakat local

c. Membuat produk atau cindreamata khas Wair Nokerua untuk menarik wisatawan

2. Strategi WO (Weaknesess Opportunities / Kelemahan Peluang) 
a. Memperbaiki infratruktur yang ada di kawasan wisata Wair Nokerua, sehingga mampu menarik wisatawan untuk berkunjung ke Wair Nokerua

b. Membangun berbagai tipe atau jenis akomodasi yang lebih beragam

3. Strategi ST (Strengths Threats / Kekuatan Ancaman)

a. Melakukan inovasi agar terlihat lebih berbeda dengan objek wisata sejenis di sekitarnya

b. Melakukan edukasi atau pelatihanpelatihan bagi sumberdaya manusia

c. Melakukan edukasi atau pelatihanpelatihan bagi sumberdaya

d. Meningkatkan kewaspadaan terhadap berbagai hal yang dapat mengganggu kenyamanan wisatawa

e. Menyediakan fasilitas yang memadai agar wisatawan merasa nyaman saat berkunjung

4. Strategi WT (Weaknesess Threat / Kelemahan Ancaman)

a. Menciptakan berbagai aktivitas wisata yang bisa dilakukan oleh wisatawan agar mampu bersaing dengan produk wisata serupa

b. Bekerjasama dengan pemerintah dan pihak-pihak terkait dalam pembangunan infrastruktur demi kelancarannya dalam melakukan sebuah perjalanan wisata dan menjaga kelangsungan

c. Pertumbuhan wisata bahari maupun keanekaragaman hayati yang ada di dalamnya. d. Membentuk dan memperketat keamanan untuk keselamatan para wisatawan selama berkunjung ke Wair Nokeru

e. Menghimbau para nelayan dan masyarakat, serta stakeholder terkait agar selalu menjaga perairan serta keindahan alam wisata Wair Nokerua

\section{Strategi Pengembangan}

Dari analisis SWOT dan strategi S-O, S-T, W-O, W-T dapat disusun strategi pengembangan objek wisat Wair Nokerua dengan menggunakan konsep pembagian zonasi wilayah, dimana pembagian wilayah tersebut berdasarkan zona inti, zona buffer dan zona pelayanan yang dapat di lihat pada Tabel 1.

Konsep pembagian zonasi diperlukan perencanaan yang partisipatif dalam pengembangan objek wisata Wair Nokerua dengan menerapkan prinsip pembangunan berwawasan lingkungan. Pengelolaan pembangunan yang berwawasan lingkungan merupakan hal penting untuk keberlanjutan ekosistem. Hal ini dapat dilaksanakan melalui :

1. Pencegahan pencemaran lingkungan

Pencemaran lingkungan dapat menyebabkan ketidakseimbangan lingkungan atau ekosistem. Pencemaran lingkungan akan merusak keadaan yang mulanya baik menjadi tidak baik. Ketika terjadi pencemaran maka akan banyak pihak yang terganggu, bukan hanya manusia namun juga binatang hingga tumbuh- tumbuhan. Untuk itu yang perlu 
dilakukan dalam pencegahan pencemaran lingkungan pada Objek Wisata Wair Nokerua adalah memperhatikan carryng capacity area, mengatur pembuangan sampah, kampanye sadar wisata dan sapta pesona.

2. Rehabilitasi dan pemulihan ekosistem dan sumberdaya alam yang rusak.

Upaya pemulihan ekosistem dan sumberdaya alam yang rusak dilakukan dengan tujuan unutuk mengembalikan nilai, fungsi, dan manfaat lingkungan Objek Wisata Wair Nokerua. Upaya tersebut dapat dilakukan melalui berbagai cara seperti suksesi alam dengan bantuan manusia (pemulihan terumbu karang yang rusak, penanaman kembali jenis tumbuhan yang ada di wilayah pesisir, konservasi wilayah pesisir dengan penanaman bunga matahari sebagai atraksi wisata) dan meningkatkan kepedulian akan perlunya konservasi baik bagi pengelola atau masyarakat sekitar tempat wisata atau bagi wisatawan.

3. Meningkatkan kapasitas produksi dari ekosistem alam dan binaan manusia.

Peningkatan produksi dari ekosistem alam dan binaan manusia dilakukan dengan memberikan pelatihan kepada POKDARWIS yang ada di Desa Kolisia untuk meningkatkan peran dan partisipasi masyarakat dalam pembangunan objek wisata Wair Nokerua. Keterlibatan POKDARWIS yang dimulai dari awal perencanaan pengembangan objek wisata sampai pada pelaksanaan pembangunan dapat memberikan dampak positif terutama peningkatan kesadaran wisata pada lingkungan masyarakat.

Keberhasilan dalam kegiatan pembangunan berwawasan lingkungan pada objek wisata Wair Nokerua tidak hanya memprioritaskan pengembalian fungsi ekosistem wilayah pesisir tersebut, tetapi pengembangan objek wisata yang mengedepankan kesejahteraan masyarakat, baik yang ada di Desa Kolisia maupun di luar Desa Kolisia sehingga pada akhirnya tujuan pengembangan objek wisata berwawasan lingkungan dapat tercapai dengan tidak mengesampingkan masyarakat setempat.

\section{KESIMPULAN}

Strategi pengembangan objek wisata Wair Nokerua dengan prinsip berwawasan lingkungan dapat dilaksanakan melalui :

1. Pencegahan pencemaran lingkungan dengan memperhatikan carryng capacity area, mengatur pembuangan sampah, kampanye sadar wisata dan sapta pesona kepada masyarakat Desa Kolisia dan Wisatawan

2. Rehabilitasi dan pemulihan ekosistem dan sumberdaya alam yang rusak dapat dilakukan melalui berbagai cara seperti suksesi alam dengan bantuan manusia (pemulihan terumbu karang yang rusak, penanaman kembali jenis tumbuhan yang ada di wilayah pesisir, 
konservasi wilayah pesisir dengan penanaman bunga matahari sebagai atraksi wisata) dan meningkatkan kepedulian akan perlunya konservasi baik bagi pengelola atau masyarakat sekitar tempat wisata atau bagi wisatawan.

3. Meningkatkan kapasitas produksi dari ekosistem alam dan binaan manusia dengan memberikan pelatihan kepada POKDARWIS yang ada di Desa Kolisia untuk meningkatkan peran dan partisipasi masyarakat dalam pembangunan objek wisata Wair Nokerua.

\section{SARAN}

Perlu adanya penelitian lebih lanjut tentang penerapan Sapta Pesona pada objek wisata Wair Nokerua dan juga Kajian lingkungan Abiotik, biotik dan Culture pada objek wisat Wair Nokerua

\section{REFERENSI}

[1] A. Reni Widyastuti, Pengembangan Pariwisata yang Berorientasi Pada
Pelestarian Fungsi Lingkungan, Jurnal Ekosains, Vol. II, No.3, Okt. 2010.

[2] Bappeda Prov Jabar. Laporan Rencana Induk Pengembangan Pariwisata Wilayah. Bandung, 2016

[3] Nurdiansyah. Peluang dan Tantangan Pariwisata Indonesia. Bandung: CV. Alfabeta, 2014.

[4] Peraturan Menteri Dalam Negeri Nomor 33 Tahun 2009 tentang Pedoman Pengembangan Ekowisata di Daerah

[5] Rangkuti, Freddy. Analisis SWOT, Teknik Membedah Kasus Bisnis. Gramedia: Jakarta, 2003.

[6] Susmianto A. dkk. Belajar dari Lapangan: Kisah Keberhasilan Peulihan Ekosistem di Kawasan Suaka Alam dan Kawasan Pelestarian Alam Secara Partisipatif. Forda Press. 2017

[7] Sutisno dan Afendi. Penerapan Konsep Edu-Ekowisata Sebagai Media Pendidikan Karakter Berbasis Lingkungan. Vol.12 No 1 : 1-5, Jan. 2018

[8] Yoeti, Oka, A. Pariwisata Budaya: Masalah dan Solusi. Jakarta: PT.Pradnya Paramita. 2006. 


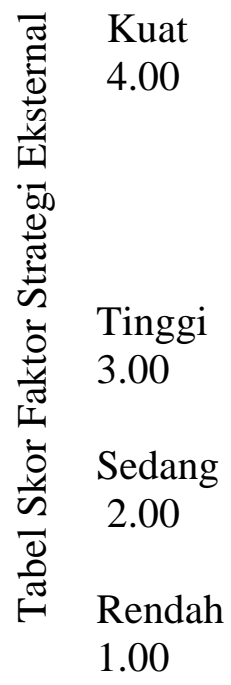

Tabel Skor Faktor Strategi Internal

$\begin{array}{llll}3.00 & 1.7 & 2.00 & 1.00\end{array}$

\begin{tabular}{|c|c|c|}
\hline \multirow{2}{*}{3.2} & I & II \\
Grow and build & Grow and build & II \\
\cline { 2 - 4 } & Hold and maintain \\
\hline IV & V & VI \\
\hline Grow and build & Hold and maintain & Harvest or divest \\
\hline VII & VIII & IX \\
& Harvest or divest & Harvest or divest \\
& & \\
& & \\
& & \\
\end{tabular}

Gambar 1

Matriks Internal Eksternal (IE)

Sumber: Hasil Analisis, 2021

Tabel 1. Pembagian Zonasi Wilayah

\begin{tabular}{|c|c|c|c|c|}
\hline Kawasan & Atraksi & Aktivitas & $\begin{array}{c}\text { Konsep } \\
\text { pengembangan }\end{array}$ & Prasarana Pendukung \\
\hline $\begin{array}{l}\text { Zona Pelayanan: } \\
\text { Wair Nokerua } \\
\text { (jalan masuk menuju } \\
\text { tempat parkir) }\end{array}$ & $\begin{array}{l}\text { Budidaya dan } \\
\text { pengelolaan } \\
\text { potensiagrowisa } \\
\text { ta }\end{array}$ & $\begin{array}{l}\text { 1. Edukasi proses penanaman } \\
\text { sayur (Pakcoy, kangkung, } \\
\text { tomat) } \\
\text { 2. Edukasi proses pembibitan } \\
\text { 3. Cooking class makanan lokal }\end{array}$ & $\begin{array}{l}\text { Wisata } \\
\text { pendidikan dan } \\
\text { pengolahan } \\
\text { agrowisata }\end{array}$ & $\begin{array}{l}\text { Fasilitas edukasi pertanian } \\
\text { berupa fasilitas pembibitan, } \\
\text { lahan atraksi, fasilitas } \\
\text { pengolahan pasca panen }\end{array}$ \\
\hline $\begin{array}{l}\text { Zona Inti : } \begin{array}{l}\text { Wair } \\
\text { Nokerua } \\
\text { pantai) }\end{array} \\
\text { (area }\end{array}$ & $\begin{array}{l}\text { Rekreasi wisata } \\
\text { bahari }\end{array}$ & $\begin{array}{l}\text { 1. Water sport seperti } \\
\text { snorkling, diving, canoing, } \\
\text { dan memancing } \\
\text { 2. Fotografi } \\
\text { 3. Outbound }\end{array}$ & Wisata bahari & $\begin{array}{l}\text { Tempat parker, MCK, } \\
\text { gazebo, Spot-spot berfoto } \\
\text { alami maupun buatan, tenda- } \\
\text { tenda glamping serta } \\
\text { fasilitas pelengkapnya }\end{array}$ \\
\hline $\begin{array}{l}\text { Zona Buffer : Mata } \\
\text { air Wair Nokerua }\end{array}$ & $\begin{array}{l}\text { Wisata Minat } \\
\text { Khusus }\end{array}$ & $\begin{array}{l}\text { 1. Ziarah rohani } \\
\text { 2. Mengambil air dari mata air } \\
\text { tersebut }\end{array}$ & $\begin{array}{l}\text { Wisata minat } \\
\text { khusus }\end{array}$ & $\begin{array}{l}\text { Jembatan atau dermaga } \\
\text { menuju mata air, transportasi } \\
\text { laut seperti sampan/perahu }\end{array}$ \\
\hline
\end{tabular}

